\title{
In Search of Identity: A Comparative Feminist Exploration of Muslim Female Sexuality in Ali's Twilight in Delhi and Shahraz's The Holy Woman
}

\author{
Fariha Chaudhary \\ Department of English \\ BZU (Sub-campus Sahiwal) \\ Qamar Khushi \\ Department of English \\ BZU Multan
}

\begin{abstract}
A critical exploration of Muslim female sexuality through the feminist analysis of the various female characters in Twilight in Delhi and The Holy Woman, by Ahmad Ali and Qaisra Shahraz respectively, is the central focus of this paper. Theoretical insights have been drawn from Islamic feminism and Postcolonial feminist scholarship for the contextual understanding of female sexuality. Focusing specifically on the issue of female sexuality and marriages, in both of the novels, this paper demonstrates that Muslim women in the postcolonial Pakistan seems to have gained a certain measure of agency as compared to the plight of women in the colonial milieu of Ali's novel. However, examined closely, as this paper will highlight, women in both of the novels, still in certain ways, remain helpless victims of sexual victimization. This comparative analysis of novels based in two varied settings of colonial and post-colonial Muslim societies reveals that female sexuality remains a stifling point of contention which is predominantly controlled by men.
\end{abstract}

Keywords: Muslim Women, Female Sexuality, Marriage, Islamic Feminism, Pakistani Literature in English

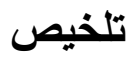

اس مقال كام كزك خيال مسلم نسو أن جنى رويول

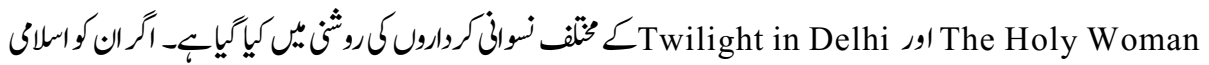

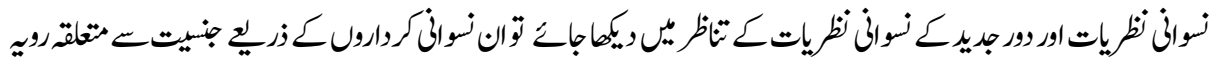

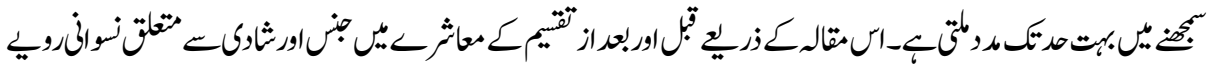

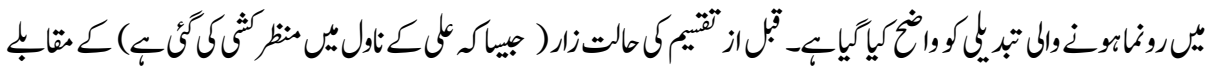

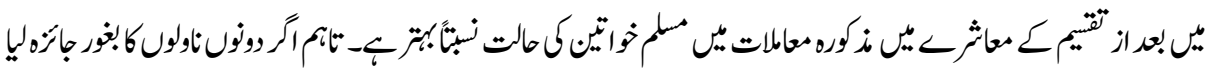

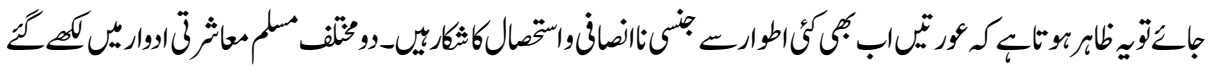




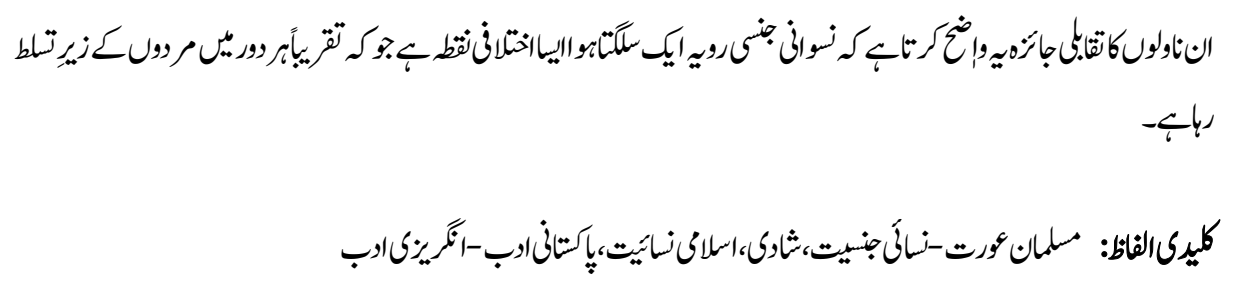

\section{Introduction}

The question of female sexuality of Muslim women has been a pressing issue in the face of mounting evidence of sexual violence against women such as rape, murder, abduction and forced marriages. Such occurrences, as reported through Pakistani media, bear testimony of the fact that female sexuality often becomes a battle ground upon which family disputes are won and lost, insults and injuries are inflicted and revenges are taken by men who own these women. Pakistani Anglophone writers have been portraying the images of Muslim women who have been grappling with the contentious issues relating to their sexuality and marriages. These women are often portrayed as torn between the emotional conflicts of duty, family and social expectations and their personal desires to act according to their will. Located within this context, the present paper focuses on the selected works of two Anglophone writers, Qaisra Shahraz and Ahmad Ali. Shahraz's The Holy Woman and Ali's Twilight in Delhi will be critically examined within the theoretical framework of postcolonial and Islamic feminism.

Ali's novel, Twilight in Delhi (1940) captures a crucial point in the history of the subcontinent showing the resistance and specifically the emotional conflict experienced by the Muslims of Delhi against the colonial impacts on their culture. Mir Nihal, the head of the family, is a member of the older generation who expresses immense pride in the glorious past of the Muslim rule and consequently is pained and angered to see the colonist culture replacing the old ways of the long lost Mughal dynasty. His son, Asghar is a member of the younger generation who keenly adopts the British style of living and this further adds to his fathers' misery. Located within this cultural clash is another important aspect of the lives of the Delhi Muslims, i.e. the position of female sexuality and women's status and treatment in the Muslim society of that time. Ali's portrayal of different women and the issues of marriages, give a rather bleak picture of the conditions of women and highlight the various oppressions, often pertaining to female sexuality within a male dominated society.

Shahraz a British based writer, of Pakistani origin, in her works, The Holy Woman (2001), Typhoon (2003) and Revolt (2013) focuses on women within the Pakistani society who suffer injustice and discrimination at the hands of their men. Shahraz also deals with the issues of female sexuality, as women struggle to make their own decisions regarding their marriages. The Holy Woman captures a struggling journey of a young Muslim woman, named Zari Bano, as her father forcefully turns her into a 'Holy Woman' by marrying her 
with the Holy Quran. Zari's feeble attempts to assert control over her sexuality are severely thwarted by her dominant father. She embarks upon a spiritual journey travelling to Malaysia and the UK as part of her preaching duties. Her ordeal comes to an end as she eventually marries the man she desires.

Focusing specifically on the issue of female sexuality and marriage, in both of the novels, this paper attempts to debate that Muslim women in the postcolonial Pakistan have no doubt gained a certain measure of agency as compared to the colonial milieu of Ali's novel. However, examined closely, women in both of the novels remain helpless victims of sexual victimisation and subordination. This paper also attempts to highlight the precarious position that female sexuality holds in the patriarchal Muslim society. Ali's novel when compared with Shiraz's provides a wonderful opportunity to see how a male and a female writer portrays female sexuality. Both Ali and Shahraz focus on the lives of Muslim women as representatives of Muslim culture of two varied settings in time. This will also allow us to see how Muslim men in both colonial and post-colonial periods continue to assert control over female sexuality.

\section{Literature Review}

Female sexuality has been a keenly researched area especially by postcolonial female writers. Katrak (2006, xi) highlights the presentation of female sexuality in the postcolonial regions as, "a politics of the female body must include the constructions and control of female sexuality, its acceptable and censored expressions, its location socioculturally, even materially in postcolonial societies. Female body and sexuality have been the most targeted sites by men not only in the colonial but also in the postcolonial era. Speaking specifically in the context of Muslim societies, men looked at their women as repositories of cultural values and religious customs. Jayawardena and Alwis (1996: x) point out a similar notion:

During colonialism, religious revivalism was a powerful opposition movement... [Which] had adverse effects on minorities and women. As many feminists have pointed out women were constructed as 'Mother of the Nation' and their biological role as reproducers of the nation was highlighted. This instrumentalised women's reproductive function and their bodies in the interest of the state... [Thus] imposing on women a new agenda as cultural carriers of tradition.

As evident women became the primary site of "re-appropriation" to challenge the culture of the colonist as well to enforce one's own cultural values. Ahmad (2012: 52) makes a similar observation:

British colonialism had affected them [women] rather negatively. They had to become the preservers of the local Mughal culture... They were just equipped with the religious education that was thought necessary 
for them to play their traditionally accepted roles of mothers and daughters within the four walls of their houses.

Spivak (1999: 304) highlights the plights of Indian women, caught amidst the conflicting forces of religion and culture during the anti-colonial struggles, in the following words:

Between patriarchy and imperialism, subject-constitution and objectformation, the figure of the woman disappears not into pristine nothingness, but into a violent shuttling that is the displaced figuration of the 'third-world-woman' caught between tradition and modernisation, culturalism and development.

Ali's Twilight in Delhi is one such example which captures the lives of Muslim women in the colonial Delhi of the 1940s. These women are shown to inhabit within high walls of their homes absorbed in their daily routines of domestic chores. Most of these women observe purdah as part of their religious and cultural duty. However, men are often portrayed to violate their share of moral piety and are further found to sexually oppress these women. For them female sexuality becomes a major site to vent their frustrations and exercise power.

\section{Ali's Women: A look into the colonial Milieu of Indian Muslim Society}

The main female characters in Twilight in Delhi such as Begum Nihal, her daughters, Mehru, and Begum Waheed, daughter-in-law Bilqeece and sister-in-law, Begum Jamal are portrayed as dedicated home-makers, devotedly engaged in the services of their men. They often find themselves at the cross roads where family duty forces them to sacrifice their inner desires. These women are presented in sharp contrast to the prostitutes of Delhi, Babban Jan and Mushtari Bai, who dwell in the publically adorned quarters, offering open invitation to the men of Delhi. Hussain (1994: 121) explains this binary opposition created in the Muslim societies of the nineteenth century sub-continent in the following words:

By the late nineteenth century two distinct stereotypes of 'good' and 'bad' woman, had coalesced in the Islamic discourse in the subcontinent. Built around the anti-theatrical images of wife and mother valorised only for her reproductive function within the domestic enclosure on the one hand and the courtesan whose productivity was closely aligned with the illicit on the other hand, these stereotypes of the feminine continue to dog out footsteps at the end of the twentieth century.

Ali's portrayal of women in Twilight in Delhi can be grouped into two categories of 'home-makers and prostitutes. Whereas the prostitutes are described as the pulse of Delhi, 
adding vigour and zeal into the lives of men, the home-maker-kind-of-women silently dwell within the boundaries of their homes and observe purdah:

In the Zenana things went on with the monotonous sameness of Indian life. No one went out anywhere. Only now and then some cousin or aunt or some other relation came to see them ......Walls stood surrounding them on all sides, shutting the women in form the prying eyes of men guarding their beauty and virtue with the millions of their bricks. The world lived and died, things happened, but all this did not disturb the equanimity of the Zenana, which had its world too where the pale and fragile beauties of the hothouse lived secluded from all outside harm, the storms that blow in the world of men. (TID: 39)

As evident from the above quotation, the 'zenanas' represent spaces that were secluded from the outside world. The inmates of the Zenanas were simple women for whom the sole purpose of their lives was the wellbeing of their family. Ali's women are preoccupied with the issues of marriages. Begum Nihal worries about her daughter Mehru's marriage. She chooses a man for her daughter who she only knows about through distant sources mainly because the man is financially well-off. Mehru is neither informed nor consulted about her marriage. Mehru is filled with a sense of uncertainty and anxiety regarding her prospective groom as she silently contemplates, lying in her bed at night:

What can he be like? She wonders. She has never seen him. They are extremely rich people, she has heard; and Meraj - that is his name - is very fond of shooting. And she associates him with the Prince in the story with whom the princess was in love" (TID: 6).

As evident, all Mehru knows about her future husband is his name and financial stability as she would be known by his name after their marriage, as Begum Meraj (wife of Meraj). This further strengthens the loss of identity ofIndian Muslim women for whom marriage means the gaining of a new identity which clearly signals her position as an object that has been possessed by a certain man that is her husband. Furthermore, Mehru fantasises her future husband as a prince and lets her imagination loose, filled with romantic fantasies. This further highlights the sexual repression and sexual ignorance of Indian Muslim women as portrayed by Ali, another aspect of their lives which brings them in a position of undue suffering. The young Mehru, at the verge of adulthood, is vaguely aware of her sexual desires which surface occasionally, especially at the mention of her future husband's name. As in one incident her young cousin teases her with the mention of Meraj's name and:

[Mehro], of course, liked it in the heart of her hearts; but the name brought her hidden wish to the surface with a rude suddenness that not only disturbed her emotional balance, but also exposed inhibitions 
which grew in the repressed lives of the Indian Muslim women like cobwebs and mushrooms. To conceal her consciousness of sex she flew into a temper, without of course, realising its unconscious and hidden cause. Meraj's name fell on her ears with a splash like a stone in the midst of a stagnant water of a pond which setup a whirlpool of waves rushing one after another. From nowhere a storm wells up for a while and disturbs the placidity of the pond's static life (TID: 40-41).

As evident through Mehro's emotional turmoil, Muslim Indian women lived their lives like stagnant pools of water, confined within the boundaries of their homes and fixed routines of domestic chores. The only source of happiness or change that comes into their lives is almost entirely at the cost of their husbands, be it the mere mention of their name, as in Mehru's case or their companionship as in Bilqeece's case.

Bilqeece is another young women who is married to Asghar, Nihal's youngest son. Asghar chooses the docile and humble Bilqeece as his wife because she reflects the beautiful Mushtari Bhai that Asghar is mesmerised by. He expects Bilqeece to behave in a flirtatious manner, cajoling him. Bilqeece is too shy to respond to her husband's playful flirtations and is ignorant of the ways to please men. Both Mehru and Bilqeece represent typical young Indian Muslim girls of that time who silently marry any man chosen by their families and are schooled in the art of perfect wives from the tender years of their lives. Almost all of the married women within the novel observe strict adherence with the dictates of duty-bound and faithful wives even after the deaths of their husbands. For example, Nihal's eldest daughter, Begum Waheed and sister-in-law, Begum Jamal both become widows at an early age and both of them never remarry, partly due to the social custom of the time and partly due to the love and respect of their departed husbands. Another point to be noted regarding marriage in Twilight in Delhi is that love based marriage is the prerogative of the men only whereas female characters are seldom shown to succeed in their love based marriages. For example, Asghar falls madly in love with Bilqeece and manages to marry her even against the wishes of his father. On the other hand, Zohra, who, after the death of her sister, begins to take interest in Asghar and wishes to marry him is not only reprimanded by her mother but is also forcefully married away to someone else in haste.

Ali's Men, on the other hand, are portrayed as sexually promiscuous and taking liberty with women around them. For instance, Nihal secretly indulges in many love affairs with various women including his servant woman, Dilchain, and a famous prostitute, Babban Jan. Nihal's sexual relations with Dilchain become cause of a conflict between Nihal and Begum Nihal. However, Begum Nihal is unable to confront her husband regarding this issue and finds solace in crying and lamenting like a madwoman. She is temporarily sent to live in an abandoned house near a graveyard to cure her of her madness. Nihal roams around unbothered by the mental stress his wife endures as a result of his infidelity. Thus, 
marriage is not taken as a sacred relationship demanding total faithfulness as far as Ali's male characters are concerned. For them women are things to derive pleasure from, be it within the four walls of their home or the adorned quarters of prostitutes. Moreover, they have no qualms about re-marrying a second or a third time. Saeed, Nihal's eldest son-in-law, remarries shortly after his wife dies. Similarly, Nihal's servant, Ghafoor, also remarries and even Asghar, after the death of Bilqeece falls passionately in love with Bilqeece's younger sister, Zohra, and makes advances towards her and later desperately wishes to marry her.

Both, Nihal and Asghar, are captivated by the physical beauty of the prostitutes they visit. Throughout the novel feminine beauty is emphasised upon. Female sexuality is portrayed as an active and potentially dangerous weapon capable of causing great harm to men as one of the Qawals near Mir Nihal's house sings:

She aimed a poisons arrow

Straight from her eyes at me

She looks at one and hits another, How cruel and clever is she!

(Twilight in Delhi: 50)

Similarly, Budho, Durgi Chamari's daughter, has been described as a sensuous young woman who looks into the eyes of men. Asghar's friend, Hameed, was a young boy who fell in love with her and later went mad as Asghar expresses, "He was too gentle for her, too good and simple. No wonder he had gone mad" (pg., 54). Budho is thus presented as a woman who is capable of rendering men as mad with her mystical physical beauty. Men, on the other hand, are portrayed as helpless victims of female sexuality which possess great power to allure the men into helpless stupor. Just as Asghar falls helplessly in love with Bilqeece after getting a glimpse of her. He expresses her beauty to his friend, Bari, in the following words:

She is beautiful, Bari, very beautiful. She is graceful as a cypress. Her hair is blacker than the night of separation, and her face is brighter than the hours of love. Her eyes are like narcissi, big and beautiful. There is nectar in their whites and poison in their blacks. Her eyebrows are like two arched bows ready to wound the hearts of men with the arrows of their lashes. Her lips are redder than the blood of lovers, and her teeth look like pearls studded in a row... I tell you she is beautiful (TID: 32).

The prostitutes of Delhi are presented in a similar light, as women capable of working great charms on men with their beauty. Nihal and Asghar both admire the skilful ways of alluring and cajoling men used by the prostitutes and consider them as ideal lovers yet they prefer to marry simple Indian women who have lived all their lives within the four walls of their houses, are shy, modest and untrained in the art of pleasing men. However, both of these men expect their simple wives to behave in a similar flirtatious manner with 
them. Ironically, the Muslim men of Delhi seem to be confused between their desires and expectations they have of their women.

Women are thus portrayed as sexually potent and dangerous beings. Female sexuality is considered as a threatening force which needs to be controlled. This explains the early marriages of girls and also the strict adherence of purdah and limited communication with the outside world. The prostitutes present a perfect example of the lethal potentials of female sexuality which has been let loose and thus these women are equipped with all the powerful means of alluring men into their charms. In fact, the charms of their beauty and female sexuality is so powerful that both Nihal and Asghar are unable to break away from it. Furthermore, when Babban Jan, the prostitute that Nihal used to visit, dies he is unable to recover from the feeling of loss and he himself falls ill.

Asghar describes Mushtari Bai as, "a beautiful woman, young and tall: and in her dark eyes there was something piercing and poisonous" (TID: 75). Here it becomes pertinent to bring into discussion the position of female sexuality in Islam. Perhaps it might offer some insights into why these Muslim men repeatedly assign and associate destructive abilities with the physical beauty of women. Islamic scholars such as Fatima Mernissi, Miriam Cook and Margot Bandran have researched extensively regarding women's position in Islam and the precarious status of female sexuality. Female sexuality is regarded as a great potential force as Badran (2009: 170-171) describes:

Learned Islamic texts and popular belief hold that women possess enormous sexual appetites (far greater than those of men), and that woman's whole being, body and voice constitutes a sexualised entity. The word describing the 'sexualised' in Arabic is awra which literally means genitalia. That which is awra must be covered, and since in the traditional conservative view "the woman" is constructed as an "omnisexual being", women's entire bodies must be hidden and in traditional conservative culture even their voices.

This huge sexual hunger of women, as evident from the above quotation, is tamed and controlled by keeping women physically veiled from public in a separate domain usually known as zenanas. Mernissi, (1987: 16) a Moroccan Islamic feminist also expresses similar views:

In Western culture sexual inequality is based on the belief in the biological inferiority of women. In Islam it is the contrary: the whole system is based on the assumption that a woman is a powerful dangerous being.

Ali exemplifies both scenarios by presenting women who are humble purdah observing women and bold public dwelling prostitutes. The colonial milieu of Ali's novels reveals 
women who serve as objects used by men for the fulfilment of their sexual desires either through marriage or outside marriage.

\section{Shahraz's Women: A View from the Postcolonial Pakistani Society}

Shahraz's The Holy Woman presents a modern Muslim woman of the post-colonial Pakistani society in the form of Zari Bano. Unlike Ali's women, Zari is privileged enough to study in a university. Similarly, purdah for Zari is far more flexible as she is allowed to venture outside her home. As the novel begins we see Zari out in the open observing a village fair. We also learn that Zari is going through the process of selecting a bridegroom for herself. She even dresses in very fancy clothes and comes down to meet her prospective groom, Sikandar. Shahraz presents Zari as a woman who apparently has the freedom to choose her own life partner, a concept with which Ali's women were most probably unaware of. Zari's mother, like Begum Nihal is most concerned about her daughter's marriage. However, Shahzada, unlike Begum Nihal, sends her daughter for a visit to her in-laws home. Zari not only goes to visit Sikandar's house in Karachi but also dines with him in private and the two speak about their future together.

Even the village women that Shahraz presents are all independent and have the awareness of the importance of education such as Fatima's daughter, Firdaus, who wants to become a school headmistress. Similarly, marriage remains a major issue that Shahraz deals with. Zari's marriage, Firdaus's marriage, and Kaneez's marriage. Interestingly, all the women in this novel who go through marriage exercise their authority and have their say in marriage. For instance, Firdaus, is presented as a head strong girl who only agrees to marry Khawar, the man who loved her, after a long series of fights between their families. Similarly, Kaneez is a village Chaudharani who is widowed at an early age. A landlord of the neighbouring village proposes her repeatedly but she declines his proposal. It is only after a long struggle of repeated requests along with the consistent persuasion from her sister that convinces Kaneez to agree to the marriage proposal.

Perhaps the most significant development that Shahraz points out regarding the position of women within the Pakistani Post-colonial society is the issue of veil. Zari Bano begins out as a secular minded girl who is often seen to be transgressing the boundaries of purdah. As she is forced to marry the Quran, she also needs to observe strict purdah. Her forceful marriage with the Quran is another example of the male dominance and control over female sexuality. However, one positive aspect of the barbaric tradition is seen in Zari s changing attitude towards purdah that she has to observe. At first she finds purdah as a limiting and confining tool which takes away her sense of identity:

The Burqa slithered over her head, her shoulders and down to her feet.

Zari Bano stood frozen in the Burqa, dehumanised... I have been stripped of my identity and a stranger is taking my place (THW: 146). 
Zari grapples with the conflicting issue of taking purdah as a part of her identity. Shahraz shows how through observing purdah Zari is allowed to transgress the boundaries of space and social customs. As Habib points out:

My Zari Bano is to be my heiress, our Holy woman. She will become a scholar of Islam...a female symbol of purity and Ibadat in its purest form. I am thinking of sending her to Misr, Cairo University... She will attend Islamic conferences all over the world...She will not have the time or the will for mundane things-the everyday things (THW: 154).

She travels abroad for higher education and even works to preach the teachings of Islam. Her role of a Holy Woman actually allows her to break the traditional roles assigned to women and rather than capturing her, gives her a liberating experience. As Imtiaz and Haider (2011: 11) assert:

[The] veil becomes a strategy for her [Zari Bano] emancipation. The veil was intended to assert the spatial boundary but ironically it becomes the protagonist's resource for transcendence of the spatial boundary.

When compared with Ali's women of the colonial milieu, we find a stark difference in the way women comprehend the notion of purdah. Ali's work clearly signals purdah as a tool used to control and tame female sexuality whereas, Shahraz's Zari is able to use purdah as a 'power enabling tool' to challenge the position of female sexuality in a male dominated society. As Imtiaz and Haider further point out that after observing purdah Zari Bano ceases to a sexual object or a passive recipient of love from Sikandar, rather she becomes an active agent who exercises her free will in deciding her marriage partner at the end of the novel.

\section{Discussion and Conclusions}

The portrayal of women as presented by Ali and Shahraz, in two different settings, clearly indicate a certain sense of agency gained by women in the postcolonial Pakistani society. Shahraz through the character of Zari challenges the colonial presentations of Muslim women. In other words, Shahraz seems to claim that Muslim women of today are articulate enough to realise and speak about their own issues. Specifically through veil as a symbol, she shows how Zari creates her own meaning of veil and confesses that veil is something freely chosen by her and not an imposition on her.

Shahraz works as a representative for the Third World Women, being more privileged and having access to the English language, makes an excellent attempt to show to the Western world that it is time now to rethink and grow out of the commonly held notions of Muslim women being, "[presented] as exotic maidens, subject of male power fantasy" 
(Imtiaz and Haider, 2006: 15).Shahraz, being a female writer, shows a more sympathetic approach and understanding to women's issues in a patriarchal society. Whereas Ali shows Muslim women either as virtuous humble, husband worshiping house wives whose sexuality has been channelled through marriage or prostitutes who have become active agents possessing unlimited sexual power, potentially dangerous for men in a Muslim society. Shahraz, on the other hand, presents a new perspective through Zari as a Muslim woman who at first experiences sexual exploitations at the hands of her father, but later succeeds in asserting her own will regarding her decision to marry. Most importantly she retains the practice of observing purdah yet challenges and transgresses its symbolic associations and enters into the public domain without being a sexual threat to men. Thus, it can be safely asserted that Shahraz presents a much more dynamic portrayal of a Muslim woman of the present day who clearly challenges the long held stereotypes of colonial origin regarding Muslim women.

This dynamic presentation of modern Muslim females, as presented by Shahraz is still by no means a suggestion that women have completely succeeded in breaking out of the patriarchal shackles in the present day Pakistani society. On the contrary, Shahraz reveals that this journey is rife with emotional turmoil, compromises, blackmails and sexual exploitations at the hands of men. Close examination reveals that female sexuality is at times bartered to uphold traditional and cultural values. For example, Zari is forcefully married with the Quran by her father in order to keep his family lands and property in the family and is denied the right to marry. Similarly, Shahzada, Zari's mother who sends her daughter to visit Sikandar prior to marriage is severely reprimanded by her husband and father-in-law and is threatened by divorce. In fact what remains striking is that Habib is offended by Zari's approving gaze directed at Sikandar as her mother later confides in her, "He was afraid of losing you to him. He glimpsed something in your eyes that he had never seen before for any suitor and simply couldn't cope with it" (THW: 445). This suppression of romantic association of women is a clear indication of suppression and denial of female desire and sexuality.

A similar case is found in Twilight in Delhi of Bilqeece's younger sister, Zohra, who is severely reprimanded at the expression of passionate feelings for Asghar. Whereas Asghar had succeeded in his love with Bilqeece, as a man, women in both of the novels find it difficult to bring their romantic associations to concrete form through marriage. In fact Habib in The Holy Woman shames Zari for "wanting a man" thus lending lustful connotations to her otherwise naïve expressions of love for Sikandar. This deliberate association of female expression of love with wantonness is synonymous to depriving female figure a right to claim her sexuality. And also to keep her within the limits of 'patriarchal traditions'. 
Thus, it can be safely concluded that female sexuality seemed to be an arena of men's exercise of power as presented in the colonial milieu of Ali's novel and still continues to be a stifling point of contention for men of postcolonial Pakistani society. Though certain changes have loosened the patriarchal grip over women, however, it is still a long way to go till women in Pakistan can be allowed a claim over her own body and sexuality. Till then it is a search of identity that marks her journey at the cost of bodily exploitation, at times, in the name of culture and tradition and, at others, in the name of religion.

\section{References}

Ahmad, Z. (2012). Representations of Women in Ali's Twilight in Delhi, International Journal of Research in Linguistics and Lexicography: INTJR-LL 1(4), pp. 49-55.

Ahmed, A. L. I. N. (1940). Twilight in Delhi, A Novel, Hogarth Press, London.

Badran, M. (2009). Feminism in Islam: Secular and Religious Convergences, England: Oneworld Publications.

Haider, S. \& Imtiaz, S. (2011). Under Western Eyes: Deconstructing the Colonial Representations in Qaisra Shahraz's The Holy Woman. In: Kidwai R, Siddiqui AM (eds) The Holy and the Unholy: Critical Essays on Qaisra Shahraz's Fiction. New Delhi: Sarup Book Publishers, pp.1-25.

Hussain, N. (1994). Women as Objects and Women as Subjects Within Fundamentalist Discourse. In: Khan SN and et.al (eds) Locating the Self: Perspectives on Women and Multiple Identities. Pakistan: ASR Publications, pp.108-134.

Jayawardena, K. \& De-Alwis, M. (1996). Embodied Violence: Communalising Women's Sexuality in South Asia, London: Zed Publishers.

Katrak, H. K. (2006). Politics of the Female Body: Postcolonial Women Writers of the Third World, New Brunswick, Rutgers University Press.

Mernissi, F. (1987). The Meaning of Spatial Boundaries, In: Mernissi F (eds) Beyond the Veil: Male-Female Dynamics in Modern Muslim Society. London: Al Saqi Books, pp.137-147.

Shahraz, Q. (2001). The Holy Woman, Pakistan: Black Amber Books.

Spivak, CG. (1999). A Critique of Postcolonial Reason: Towards A History of the Vanishing Present, Cambridge: Haward University Press. 
Dr. Fariha Chaudhary is Assistant Professor in the Department of English, BZU (Subcampus Sahiwal).

Dr. Qamar Khushi is Assistant Professor in the Department of English, BZU Multan. 